\title{
Accumulation of Polychlorinated Biphenyls (PCBS) in Soil and Water from Electrical Transformers Installation Sites in Selected Locations in Jos Metropolis, Plateau State, Nigeria
}

\author{
Ibrahim EG ${ }^{1^{*}}$, Gushit $\mathrm{JS}^{2}$, Salami $\mathrm{SJ}^{2}$ and Dalen $\mathbf{M B}^{2}$
}

${ }^{1}$ Department of Chemistry, Plateau State University Bokkos, Jos, Plateau State, Nigeria

${ }^{2}$ Department of Chemistry, University of Jos, Jos, Plateau State, Nigeria

"Corresponding author: Ibrahim EG, Department of Chemistry, Plateau State University Bokkos, Jos, Plateau State, Nigeria, Tel: +234548974888; E-mail: ezekiel_ibrahim@yahoo.com

Received: March 03, 2018; Accepted: April 09, 2018; Published: April 15, 2018

Copyright: ( $2018 \mathrm{Ibrahim} \mathrm{EG,} \mathrm{et} \mathrm{al.} \mathrm{This} \mathrm{is} \mathrm{an} \mathrm{open-access} \mathrm{article} \mathrm{distributed} \mathrm{under} \mathrm{the} \mathrm{terms} \mathrm{of} \mathrm{the} \mathrm{Creative} \mathrm{Commons} \mathrm{Attribution} \mathrm{License,} \mathrm{which} \mathrm{permits} \mathrm{unrestricted}$ use, distribution, and reproduction in any medium, provided the original author and source are credited.

\begin{abstract}
Soil and water samples from surroundings of selected Electricity Transformer installations belonging to the Jos Electricity Distribution (JED) Plc, Jos were analyzed for different congeners of polychlorinated biphenyls (PCBs) widely used as coolants. The EPA 3550 and 3510 methods were used for the sampling, preparation and extraction of the soil and water samples respectively. The extracts were cleaned up using column chromatography packed with silica gel (120 mesh). Thereafter, it was concentrated for characterization and quantification using Gas Chromatography coupled with Mass Spectroscopy Detector (GC-MSD). Fifteen (15) congeners were identified and quantified in the soil samples. The result obtained shows $C_{52}$ to have the highest concentration with the value of $5.84 \mathrm{mg} / \mathrm{kg}$. The range for the concentrations of the various congeners identified are: $C_{18}(0.00-0.05 \mathrm{mg} / \mathrm{kg}), \mathrm{C}_{20}$ $(0.27-0.70 \mathrm{mg} / \mathrm{kg}), \mathrm{C}_{28}(0.28-0.39 \mathrm{mg} / \mathrm{kg}), \mathrm{C}_{29}(0.28-0.39 \mathrm{mg} / \mathrm{kg}), \mathrm{C}_{44}(0.15-0.54 \mathrm{mg} / \mathrm{kg}), \mathrm{C}_{52}(0.09-5.84 \mathrm{mg} / \mathrm{kg})$, $\mathrm{C}_{101}(0.38-0.51 \mathrm{mg} / \mathrm{kg}), \mathrm{C}_{137}(0.45-1.79 \mathrm{mg} / \mathrm{kg}), \mathrm{C}_{142}(0.00-0.55 \mathrm{mg} / \mathrm{kg}), \mathrm{C}_{153}(0.37-1.20 \mathrm{mg} / \mathrm{kg}), \mathrm{C}_{170}(0.15-1.59$ $\mathrm{mg} / \mathrm{kg}), \mathrm{C}_{180}(0.00-0.47 \mathrm{mg} / \mathrm{kg})$ and $\mathrm{C}_{194}(0.00-0.32 \mathrm{mg} / \mathrm{kg})$. Similarly, for the water samples only $\mathrm{C}_{20}, \mathrm{C}_{28}, \mathrm{C}_{29}, \mathrm{C}_{101}$, $\mathrm{C}_{105}$ and $\mathrm{C}_{153}$ were identified and quantified. The result shows $\mathrm{C}_{153}$ having the highest concentration with the value of $0.57 \mathrm{mg} / \mathrm{l}$ followed by $\mathrm{C}_{105}(0.48 \mathrm{mg} / \mathrm{l}), \mathrm{C}_{101}(0.37 \mathrm{mg} / \mathrm{l}), \mathrm{C}_{28}$ and $\mathrm{C}_{29}$ have same concentration of $0.28 \mathrm{mg} / \mathrm{l}$. From thirty samples analyzed, the result of the soils is below the Canadian Reference maximum allowable limit while that of water has some values higher than the recommended allowable limit. The studies showed various concentrations are link with ages of Transformer installation, as those installed earlier had more congeners with higher concentrations than the recent ones.
\end{abstract}

Keywords: PCBs; Congener; Transformer; GC-MSD

\section{Introduction}

Polychlorinated Biphenyl (PCBs) are industrial chemical that were manufactured under the trade name Aroclor for use in transformers, electrical equipment, motor oils, paint and numerous other application. They are large class of compounds produced by partial or complete chlorination of biphenyls molecules with a general molecular formula of $\mathrm{C}_{12} \mathrm{H}_{10-\mathrm{n}} \mathrm{Cl}_{n}$ where $\mathrm{n}$ ranges from one to ten $[1,2]$. Although banned thirty-five years ago, these contaminants are still widely detected in humans and the environment [3]. They were first synthesized in 1864 [4] and were commercially produced in the United States in 1929 in response to the electrical industry's need [5] but the production was banned in the United States in 1977 due to potential health hazard such as disturbances in the liver, nausea, vomiting, jaundice, fatigue, alteration of lipid metabolism, hormonal changes, respiratory tract infection and they are also known to be carcinogen [6]. There has been a global concern of PCBs because of their potential adverse on various organism including humans such as endocrines disrupting capacities, tendency to accumulate in living organism because of their love for fat [7]. Polychlorinated biphenyls primarily accumulate in soil and sediments as a result of spills, leaking toxic landfill or contamination from products containing the chemicals. PCBs do pollute air via volatilization and dispersion, the contaminants are most problematic in soil and sediments where they adhere to organic and are very slow to degrade. The primary route of exposure for humans and wildlife is through the ingestion of contaminated dietary items. PCBs are highly lipophilic and dissolve in fatty tissue and bioaccumulate over an organism's life span. PCBs are broad category compounds consisting of 209 individual congers differentiated by the position and number of chlorine that makes up the molecules [8].

The degree of lipophilicity increases with increase in chlorination. The use of PCBs in electrical transformers is the single largest sources of PCBs in vast majority of developing countries, additional sources of PCBs may come from the illegal dumping of toxic wastes containing these chemicals. For instance, in 1987 an Italian company slipped and dumped illegal 8000 drums of PCBs in a small-town Koko in the Nigerian Delta [9] PCBs are not produced in Nigeria, but its source has been attributed mainly to the importation and use of transformers and capacitors containing PCBs transformer oils [10]. Studies have also shown that PCBs are present in Nigeria environment [11,12], this may be as a result of poor handling of damaged electrical equipment, leakages, spillage during refilling and indiscriminate dumping of PCBs containing wastes [13]. Therefore, this study seeks to investigate and assess the concentration of PCBs in soil and water from some selected soil of PHCN transformers in Jos metropolis, Plateau state. 
Citation: Ibrahim EG, Gushit JS, Salami SJ, Dalen MB (2018) Accumulation of Polychlorinated Biphenyls (PCBS) in Soil and Water from Electrical Transformers Installation Sites in Selected Locations in Jos Metropolis, Plateau State, Nigeria. J Environ Anal Toxicol 8: 561. doi:10.4172/2161-0525.1000561

Page 2 of 6

\section{Materials and Methods}

\section{Study area}

Jos is a city in the center of Nigeria, the city has a population of about 900,000 resident based on 2006 census [14]. It is the administrative capital of plateau state. The city is located on the Jos plateau at an elevation of about 1,238 meters or 4,062 feet high above sea level. During British colonial rule, Jos was an important center for tin mining. This city is situated at an altitude of $1,217 \mathrm{~m}(3,993 \mathrm{ft})$ above sea level. Jos enjoys a more temperate climate than much of the rest of Nigeria. Average monthly temperature ranges from $21-25^{\circ} \mathrm{C}$ $\left(70-77^{\circ} \mathrm{F}\right)$ and from mid-November to late January, night time temperature drops as low as $11^{\circ} \mathrm{C}\left(52^{\circ} \mathrm{F}\right)$. Jos receives about 1,400 millimeters (55 inches) of rainfall annually (Figures 1-3).

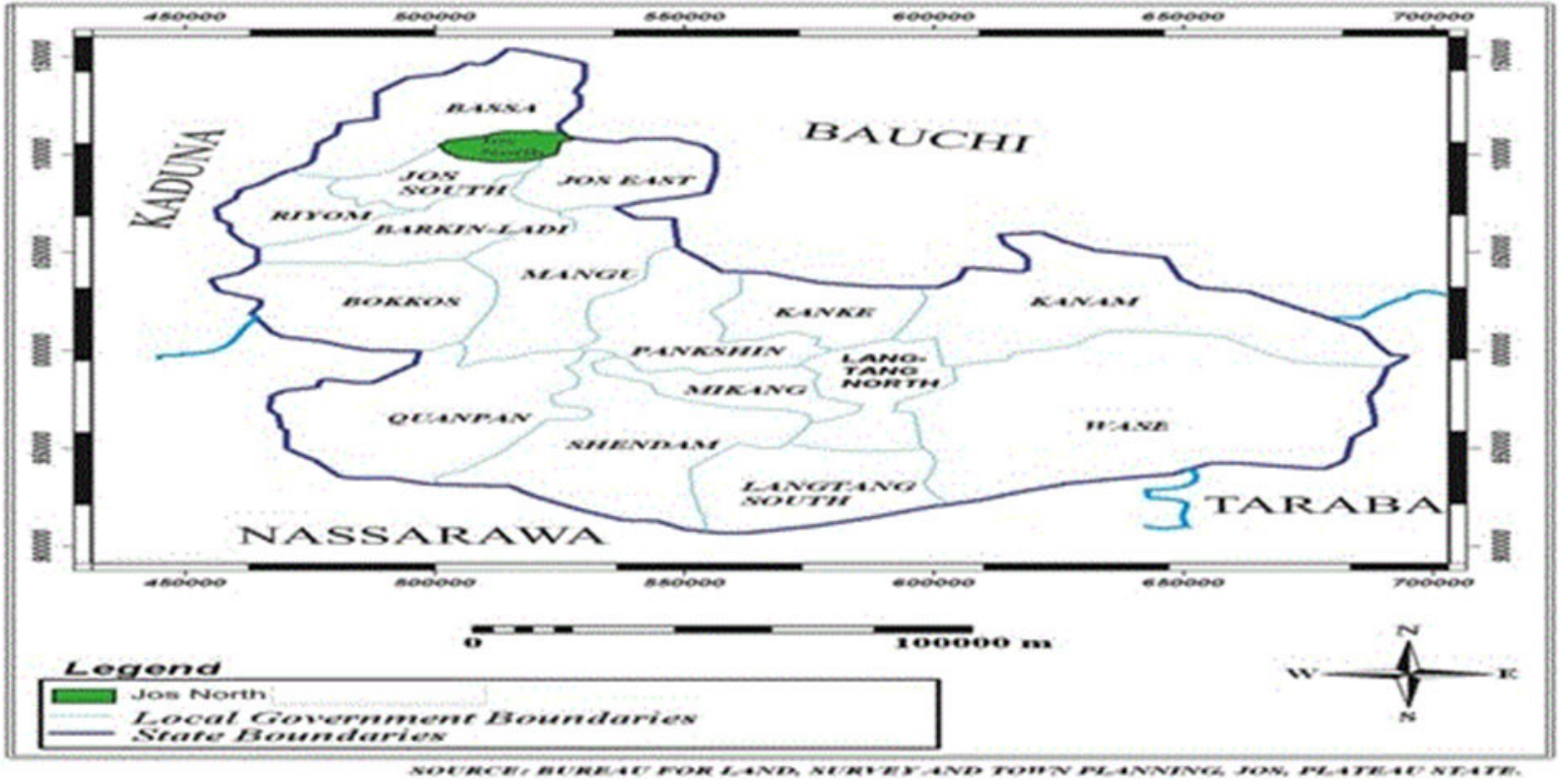

Figure 1: Map of Plateau State indicating Jos North.

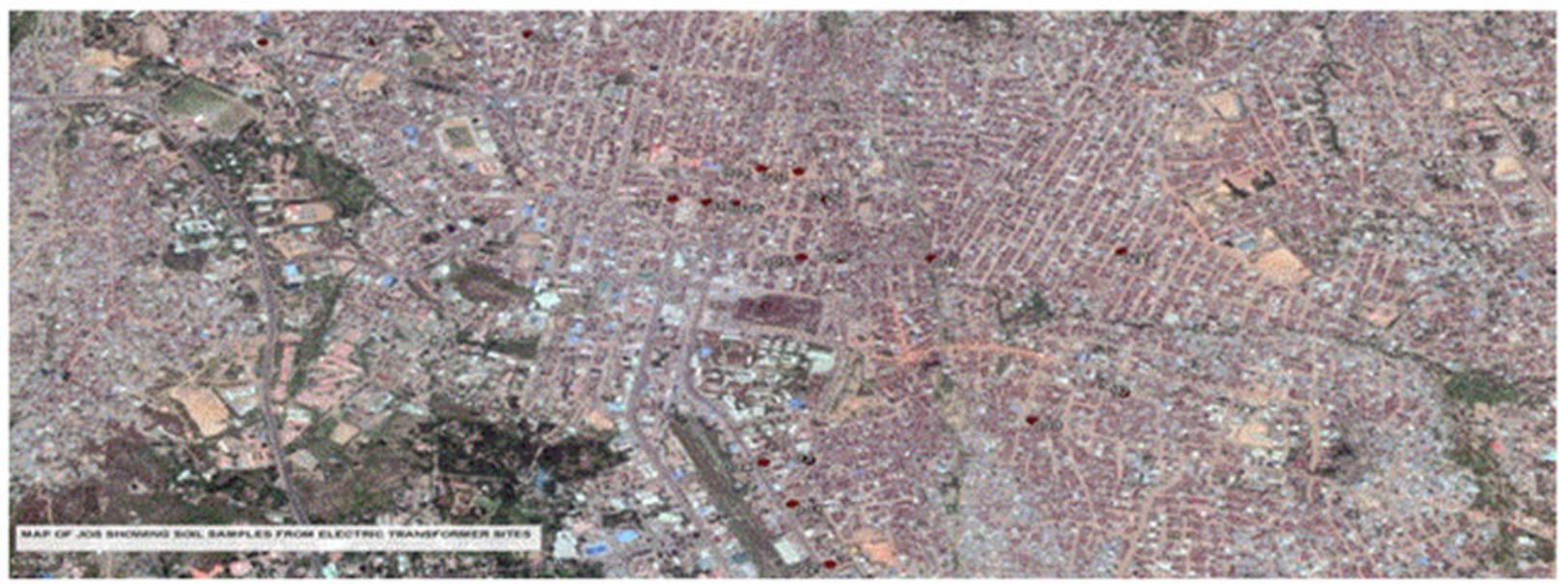

Figure 2: Sampling point. 
Citation: Ibrahim EG, Gushit JS, Salami SJ, Dalen MB (2018) Accumulation of Polychlorinated Biphenyls (PCBS) in Soil and Water from Electrical Transformers Installation Sites in Selected Locations in Jos Metropolis, Plateau State, Nigeria. J Environ Anal Toxicol 8: 561. doi:10.4172/2161-0525.1000561
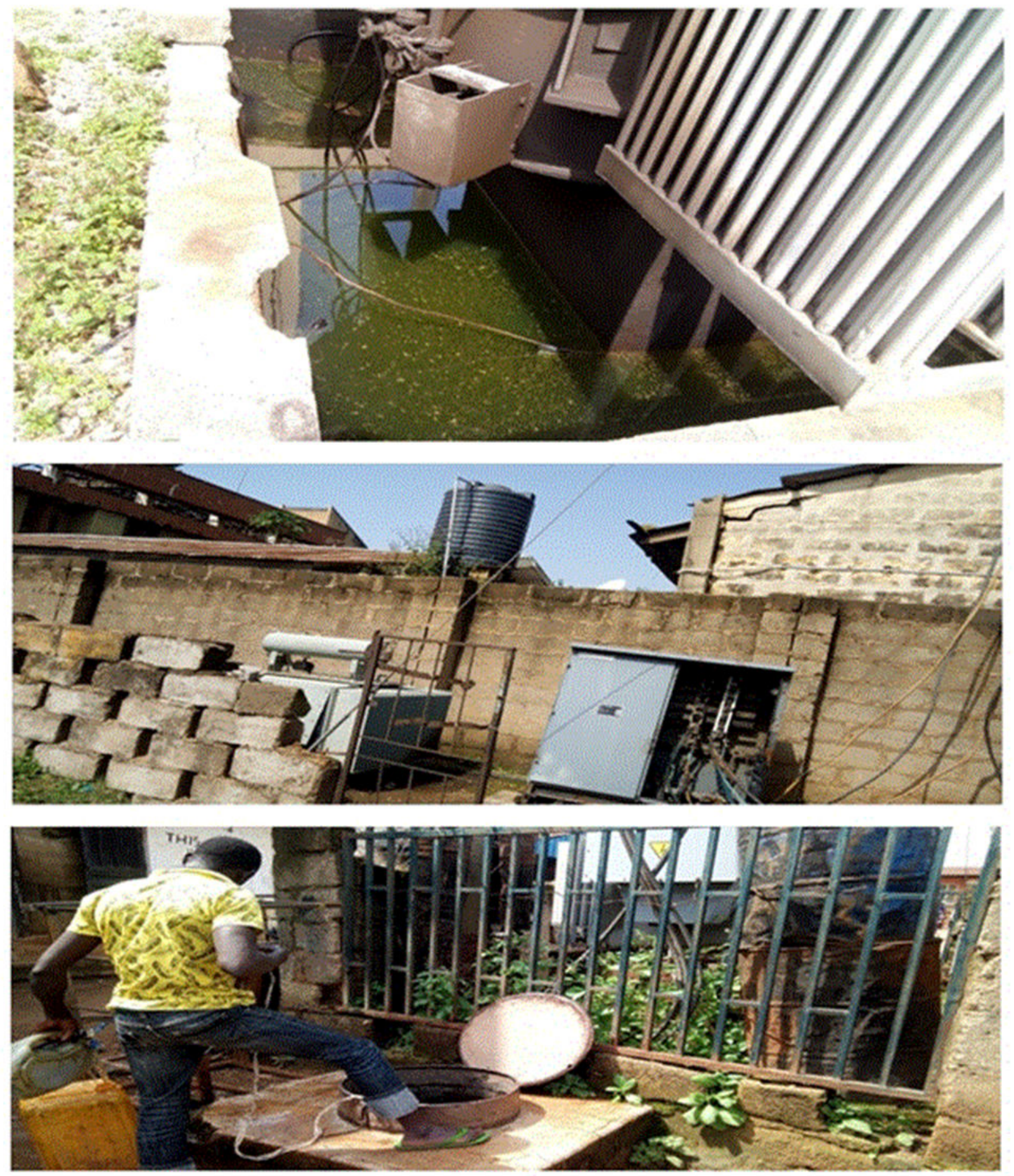

Figure 3: Transformers and the dug wells.

\section{Sampling and sample preparation}

The samples were collected in August 2017 at various locations of transformers in different site within Jos north metropolis. Soils samples were collected within Jos north metropolis. Soils sample were collected within $10-15 \mathrm{~cm}$ using splade that has been thoroughly washed rinsed with distilled water into aluminum foil, sealed, labeled and placed in an ice chest cooler while the water samples were collected from dung well into pre-washed amber glass bottle preserved with $1 \mathrm{ml}$ concentrated $\mathrm{HCl}$ bottled, sealed and put into an ice chest cooler and transported to Plateau state University Chemistry 
Citation: Ibrahim EG, Gushit JS, Salami SJ, Dalen MB (2018) Accumulation of Polychlorinated Biphenyls (PCBS) in Soil and Water from Electrical Transformers Installation Sites in Selected Locations in Jos Metropolis, Plateau State, Nigeria. J Environ Anal Toxicol 8: 561. doi:10.4172/2161-0525.1000561

Page 4 of 6

laboratory for further treatment. At the laboratory $10 \mathrm{~g}$ on the soil sample was mixed thoroughly with anhydrous sodium sulphate, this was then transferred into a beaker and added $40 \mathrm{ml}$ hexane: acetone (1:1) and placed into an ultrasonic bath and sonicate for twenty minutes, the solvent layer was allowed to settle and the solvent layer was decanted and concentrated down to $2 \mathrm{ml}$ using a rotary evaporator [15]. For water samples $200 \mathrm{ml}$ was extracted with $10 \mathrm{ml}$ of dichloromethane in separating funnel (EPA 3510) both extracts were cleaned using column chromatography and the extracts of both soil and water samples were identified and quantified using Agilent 7890 AGC coupled with 5975 MSD (Tables 1 and 2).

\section{Results and Discussion}

Table 1 and Figure 4 summarized the analytical results PCBs identified and qualified in soil with the ages of the transformers sites fifteen PCBs congener were identified and quantified but all the concentration were below the Alberta Environmental standard value for industrial soil of $33 \mathrm{mg} / \mathrm{kg}[5,16]$. The results form Table 1 shows that congener $\mathrm{C}_{52}$ at simple location has the highest value of 5.84 $\mathrm{mg} / \mathrm{kg}$ followed by congener $\mathrm{C}_{137}$ with $1.79 \mathrm{mg} / \mathrm{kg}$ and least with congener $\mathrm{C}_{18}$ in sampling point 1 . From the same Table 1 it is clear that most of the transformers sites that have been installed for years have more of the PCBs congeners while those more of the PCBs congeners while those of fewer years have little concentration of these congeners or not detected because this concentration is below the defection limit. These age transformers that have those various congeners even though lower concentration seems to be as a result of oil leakages from the transformers and poor maintenance culture from the PHCN staff.

\begin{tabular}{|c|c|c|c|c|c|c|c|c|c|c|c|c|c|c|c|c|}
\hline SITE/CONGENER & $\begin{array}{l}\text { AGE } \\
\text { (YRS) }\end{array}$ & $\mathbf{C}_{18}$ & $\mathbf{C}_{20}$ & $\mathrm{C}_{28}$ & $\mathbf{C}_{29}$ & $\mathrm{C}_{44}$ & $C_{52}$ & $C_{101}$ & $\mathbf{C}_{105}$ & $\mathbf{C}_{118}$ & $\mathbf{C}_{137}$ & $C_{142}$ & $C_{153}$ & $\mathbf{C}_{170}$ & $\mathbf{C}_{180}$ & $\mathbf{C}_{194}$ \\
\hline 1 & 20 & 0.01 & 0.47 & 0.37 & 0.37 & 0.34 & 5.84 & 0.89 & 0.36 & $\mathrm{BDL}$ & 1.79 & 0.55 & 1.20 & 1.59 & 0.47 & $\mathrm{BDL}$ \\
\hline 2 & 5 & BDL & BDL & BDL & BDL & BDL & 0.09 & 0.38 & 0.17 & 0.00 & BDL & BDL & BDL & BDL & BDL & BDL \\
\hline 3 & 9 & 0.00 & 0.39 & 0.34 & 0.34 & 0.22 & 1.16 & 0.47 & 0.18 & 0.00 & 0.53 & 0.31 & 0.53 & BDL & BDL & 0.00 \\
\hline 4 & 40 & $\mathrm{BDL}$ & 0.27 & 0.28 & 0.28 & 0.17 & 0.25 & 0.43 & 0.17 & 0.00 & $\mathrm{BDL}$ & BDL & BDL & $\mathrm{BDL}$ & $\mathrm{BDL}$ & $\mathrm{BDL}$ \\
\hline 5 & 3 & $\mathrm{BDL}$ & $\mathrm{BDL}$ & $\mathrm{BDL}$ & $\mathrm{BDL}$ & $\mathrm{BDL}$ & $\mathrm{BDL}$ & 0.38 & $\mathrm{BDL}$ & $\mathrm{BDL}$ & 0.45 & $\mathrm{BDL}$ & $\mathrm{BDL}$ & $\mathrm{BDL}$ & $\mathrm{BDL}$ & $\mathrm{BDL}$ \\
\hline 6 & 25 & 0.05 & 0.86 & 0.39 & 0.39 & 0.54 & 3.86 & 0.55 & 0.21 & 0.00 & 1.21 & 0.45 & 0.78 & 0.19 & $\mathrm{BDL}$ & $\mathrm{BDL}$ \\
\hline 7 & 7 & $\mathrm{BDL}$ & $\mathrm{BDL}$ & $\mathrm{BDL}$ & $\mathrm{BDL}$ & 0.15 & $\mathrm{BDL}$ & 0.54 & 0.26 & 0.00 & $\mathrm{BDL}$ & $\mathrm{BDL}$ & BDL & $\mathrm{BDL}$ & $\mathrm{BDL}$ & 0.00 \\
\hline 8 & 2 & $\mathrm{BDL}$ & BDL & BDL & BDL & $\mathrm{BDL}$ & BDL & BDL & BDL & BDL & $\mathrm{BDL}$ & $\mathrm{BDL}$ & BDL & BDL & $\mathrm{BDL}$ & $\mathrm{BDL}$ \\
\hline 9 & 9 & 0.00 & 0.35 & 0.33 & 0.33 & 0.29 & 3.07 & 1.46 & 0.17 & 0.00 & 0.93 & 0.32 & 0.49 & 0.15 & 0.00 & 0.32 \\
\hline 10 & 12 & 0.00 & 0.70 & 0.29 & 0.29 & 0.33 & 1.64 & 0.44 & 0.17 & 0.00 & 0.45 & 0.31 & 0.43 & $\mathrm{BDL}$ & $\mathrm{BDL}$ & $\mathrm{BDL}$ \\
\hline 11 & 12 & 0.02 & 0.34 & 0.33 & 0.33 & 0.39 & 0.21 & 0.81 & 0.17 & 0.00 & 0.48 & $\mathrm{BDL}$ & $\mathrm{BDL}$ & $\mathrm{BDL}$ & $\mathrm{BDL}$ & $\mathrm{BDL}$ \\
\hline 12 & 7 & $\mathrm{BDL}$ & $\mathrm{BDL}$ & $\mathrm{BDL}$ & $\mathrm{BDL}$ & $\mathrm{BDL}$ & $\mathrm{BDL}$ & $\mathrm{BDL}$ & $\mathrm{BDL}$ & $\mathrm{BDL}$ & $\mathrm{BDL}$ & $\mathrm{BDL}$ & $\mathrm{BDL}$ & $\mathrm{BDL}$ & $\mathrm{BDL}$ & $\mathrm{BDL}$ \\
\hline 13 & 15 & $\mathrm{BDL}$ & $\mathrm{BDL}$ & BDL & $\mathrm{BDL}$ & $\mathrm{BDL}$ & $\mathrm{BDL}$ & BDL & BDL & $\mathrm{BDL}$ & $\mathrm{BDL}$ & $\mathrm{BDL}$ & BDL & $\mathrm{BDL}$ & $\mathrm{BDL}$ & $\mathrm{BDL}$ \\
\hline 14 & 5 & BDL & BDL & BDL & BDL & BDL & BDL & BDL & BDL & BDL & BDL & BDL & 0.37 & BDL & BDL & BDL \\
\hline 15 & 20 & 0.00 & 0.54 & 0.29 & 0.29 & 0.33 & 0.11 & 0.77 & 0.18 & 0.00 & 0.64 & 0.00 & 0.62 & 0.16 & 0.00 & 0.00 \\
\hline 16 & 11 & 0.00 & 0.41 & 0.38 & 0.38 & 0.17 & 0.39 & 0.61 & 0.17 & 0.00 & 0.45 & $\mathrm{BDL}$ & 0.41 & BDL & $\mathrm{BDL}$ & 0.00 \\
\hline 17 & 30 & 0.00 & 0.38 & 0.37 & 0.37 & 0.24 & 1.17 & 1.11 & 0.18 & 0.51 & 0.45 & BDL & 0.41 & $\mathrm{BDL}$ & BDL & BDL \\
\hline 18 & 15 & $\mathrm{BDL}$ & 0.30 & 0.28 & 0.28 & 0.16 & 0.56 & 0.43 & 0.18 & 0.00 & 0.49 & $\mathrm{BDL}$ & 0.41 & BDL & BDL & $\mathrm{BDL}$ \\
\hline 19 & 25 & 0.00 & 0.31 & 0.33 & 0.33 & 0.38 & 0.36 & 0.79 & 0.18 & 0.00 & 1.41 & 0.00 & 0.51 & 0.23 & 0.00 & 0.00 \\
\hline 20 & 25 & 0.00 & 0.35 & 0.30 & 0.30 & 0.21 & 1.64 & 0.85 & 0.17 & 0.03 & 0.47 & $\mathrm{BDL}$ & 0.44 & 0.15 & $\mathrm{BDL}$ & $\mathrm{BDL}$ \\
\hline
\end{tabular}

Note: $\mathrm{BDL}=$ Below the detection limit. $1=$ Gageri $\mathrm{PHCN}, 2=$ Gageri Behind Investment House, 3=Gageri Sale Hassan House, 4=Old campus Unijos, $5=$ Delimi Junction by CSC Church, 6=Hayeni Delimi, 7=Alasari8=Yakasuwa Rikkos, 9=NDLEA Rikkos, 10=Rikkos 2, 11=Yashanu Yareke, 12=AladeDelimi 13=Alade Delimi 2, 14=Sarki Street B, 15=Sarki Street A, 16=Suzuki Bauchi Rd17=Adebanyo Street, 18=Midwave Ajayi Street, 19=Zaria Byepass Jamil Motors and 20=Zaria Byepass Peace motor park. $C_{18}=2,2,5$-Trichlorobiphenyl $C_{20}=2,3,3-$ Trichlorobiphenyl $C_{28}=2,4,4-$ Trichlorobiphenyl, $C_{29}=2,4,5-$ Trichlorobiphenyl, $C_{44}=2,2,3,5-$ Tetrachlorobiphenyl, $C_{52}=2,2,5,5-$

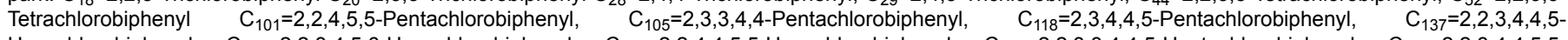
Hexachlorobiphenyl, $\quad C_{142}=2,2,3,4,5,6$-Hexachlorobiphenyl, $\quad C_{153}=2,2,4,4,5,5$-Hexachlorobiphenyl, $\quad C_{170}=2,2,3,3,4,4,5$-Heptachlorobiphenyl, $\quad C_{180}=2,2,3,4,4,5,5-$ Heptachloribiphenyl, $\mathrm{C}_{194}=2,2,3,3,4,4,5,5-$ Octachlorobiphenyl.

Table 1: Concentrations of various PCBs in soil $(\mathrm{Mg} / \mathrm{Kg})$. 
Citation: Ibrahim EG, Gushit JS, Salami SJ, Dalen MB (2018) Accumulation of Polychlorinated Biphenyls (PCBS) in Soil and Water from Electrical Transformers Installation Sites in Selected Locations in Jos Metropolis, Plateau State, Nigeria. J Environ Anal Toxicol 8: 561. doi:10.4172/2161-0525.1000561

Page 5 of 6

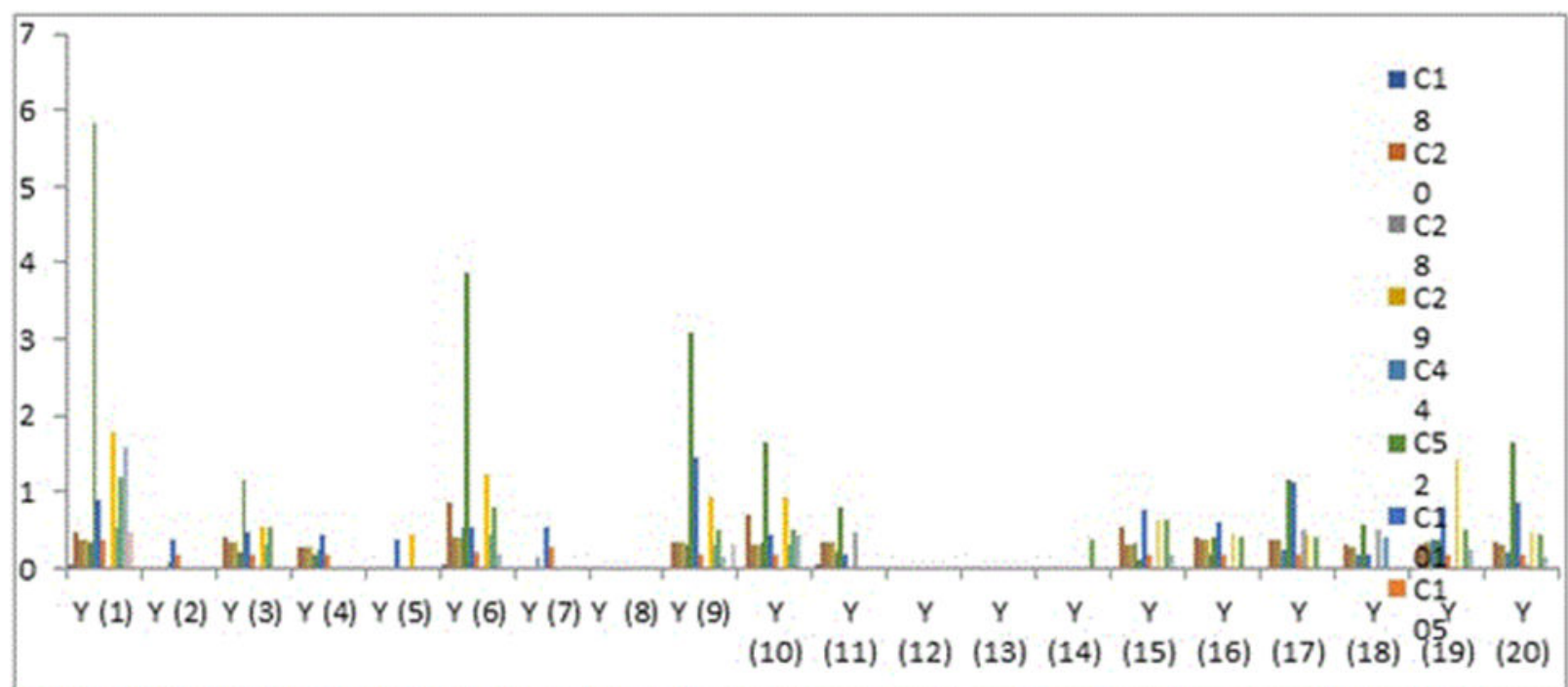

\section{Sampling Points}

Figure 4: Comparison of Various PCBS Identified in Various Samples of Soil.

Table 2 and Figure 5 shows the results of PCBs quantification in water (dug) well located within the transformer site, but most of the sampling site show that the concentration of these congeners studies were really below instrument detection limit, only congeners $\mathrm{C}_{20}$ at sampling site 4 which is $0.27 \mathrm{ppm}, \mathrm{C}_{28} / \mathrm{C}_{29}$ is $0.28 \mathrm{ppm}, \mathrm{C}_{44}(0.16 \mathrm{ppm})$ $\mathrm{C}_{101}(0.3 \mathrm{ppm})$ which is higher that Alberta standard for PCBs in ground water $(0.0094 \mathrm{ppm})$ AENV [4,15]. Table 2 also shows transformer at site 4 has more of these congeners and also older in age compare with others which may suggest as older in years of installation there is tendency of ground water pollution as a result of leakages of the oils from transformers.

\begin{tabular}{|l|l|l|l|l|l|l|l|l|l|l|l|l|l|l|l|l|}
\hline Site/Congeners & $\begin{array}{l}\text { Age } \\
(\mathrm{YRS})\end{array}$ & $\mathbf{C}_{18}$ & $\mathbf{C}_{20}$ & $\mathbf{C}_{28}$ & $\mathbf{C}_{29}$ & $\mathbf{C}_{44}$ & $\mathbf{C}_{52}$ & $\mathbf{C}_{101}$ & $\mathbf{C}_{105}$ & $\mathbf{C}_{118}$ & $\mathbf{C}_{137}$ & $\mathbf{C}_{142}$ & $\mathbf{C}_{153}$ & $\mathbf{C}_{170}$ & $\mathbf{C}_{180}$ & $\mathbf{C}_{194}$ \\
\hline 1 & 20 & $\mathrm{BDL}$ & $\mathrm{BDL}$ & $\mathrm{BDL}$ & $\mathrm{BDL}$ & $\mathrm{BDL}$ & $\mathrm{BDL}$ & $\mathrm{BDL}$ & $\mathrm{BDL}$ & $\mathrm{BDL}$ & $\mathrm{BDL}$ & $\mathrm{BDL}$ & $\mathrm{BDL}$ & $\mathrm{BDL}$ & $\mathrm{BDL}$ & $\mathrm{BDL}$ \\
\hline 3 & 9 & $\mathrm{BDL}$ & $\mathrm{BDL}$ & $\mathrm{BDL}$ & $\mathrm{BDL}$ & $\mathrm{BDL}$ & $\mathrm{BDL}$ & $\mathrm{BDL}$ & $\mathrm{BDL}$ & $\mathrm{BDL}$ & $\mathrm{BDL}$ & $\mathrm{BDL}$ & $\mathrm{BDL}$ & $\mathrm{BDL}$ & $\mathrm{BDL}$ & $\mathrm{BDL}$ \\
\hline 4 & 40 & 0.00 & 0.27 & 0.28 & 0.28 & 0.16 & $\mathrm{BDL}$ & 0.37 & $\mathrm{BDL}$ & $\mathrm{BDL}$ & $\mathrm{BDL}$ & $\mathrm{BDL}$ & $\mathrm{BDL}$ & $\mathrm{BDL}$ & $\mathrm{BDL}$ & $\mathrm{BDL}$ \\
\hline 6 & 25 & $\mathrm{BDL}$ & $\mathrm{BDL}$ & $\mathrm{BDL}$ & $\mathrm{BDL}$ & $\mathrm{BDL}$ & $\mathrm{BDL}$ & $\mathrm{BDL}$ & 0.48 & 0.00 & $\mathrm{BDL}$ & $\mathrm{BDL}$ & 0.57 & $\mathrm{BDL}$ & $\mathrm{BDL}$ & $\mathrm{BDL}$ \\
\hline 7 & 7 & $\mathrm{BDL}$ & $\mathrm{BDL}$ & $\mathrm{BDL}$ & $\mathrm{BDL}$ & $\mathrm{BDL}$ & $\mathrm{BDL}$ & $\mathrm{BDL}$ & $\mathrm{BDL}$ & $\mathrm{BDL}$ & $\mathrm{BDL}$ & $\mathrm{BDL}$ & $\mathrm{BDL}$ & $\mathrm{BDL}$ & $\mathrm{BDL}$ & $\mathrm{BDL}$ \\
\hline 11 & 12 & $\mathrm{BDL}$ & $\mathrm{BDL}$ & $\mathrm{BDL}$ & $\mathrm{BDL}$ & $\mathrm{BDL}$ & $\mathrm{BDL}$ & 0.17 & $\mathrm{BDL}$ & $\mathrm{BDL}$ & $\mathrm{BDL}$ & $\mathrm{BDL}$ & $\mathrm{BDL}$ & $\mathrm{BDL}$ & $\mathrm{BDL}$ & $\mathrm{BDL}$ \\
\hline 12 & 7 & $\mathrm{BDL}$ & $\mathrm{BDL}$ & $\mathrm{BDL}$ & $\mathrm{BDL}$ & $\mathrm{BDL}$ & $\mathrm{BDL}$ & $\mathrm{BDL}$ & $\mathrm{BDL}$ & $\mathrm{BDL}$ & $\mathrm{BDL}$ & $\mathrm{BDL}$ & $\mathrm{BDL}$ & $\mathrm{BDL}$ & $\mathrm{BDL}$ & $\mathrm{BDL}$ \\
\hline 13 & 7 & $\mathrm{BDL}$ & $\mathrm{BDL}$ & $\mathrm{BDL}$ & $\mathrm{BDL}$ & $\mathrm{BDL}$ & $\mathrm{BDL}$ & $\mathrm{BDL}$ & $\mathrm{BDL}$ & $\mathrm{BDL}$ & $\mathrm{BDL}$ & $\mathrm{BDL}$ & $\mathrm{BDL}$ & $\mathrm{BDL}$ & $\mathrm{BDL}$ & $\mathrm{BDL}$ \\
\hline 14 & 5 & $\mathrm{BDL}$ & $\mathrm{BDL}$ & $\mathrm{BDL}$ & $\mathrm{BDL}$ & $\mathrm{BDL}$ & $\mathrm{BDL}$ & $\mathrm{BDL}$ & $\mathrm{BDL}$ & $\mathrm{BDL}$ & $\mathrm{BDL}$ & $\mathrm{BDL}$ & $\mathrm{BDL}$ & $\mathrm{BDL}$ & $\mathrm{BDL}$ & $\mathrm{BDL}$ \\
\hline 15 & 20 & $\mathrm{BDL}$ & $\mathrm{BDL}$ & $\mathrm{BDL}$ & $\mathrm{BDL}$ & $\mathrm{BDL}$ & $\mathrm{BDL}$ & $\mathrm{BDL}$ & $\mathrm{BDL}$ & $\mathrm{BDL}$ & $\mathrm{BDL}$ & $\mathrm{BDL}$ & $\mathrm{BDL}$ & $\mathrm{BDL}$ & $\mathrm{BDL}$ & $\mathrm{BDL}$ \\
\hline
\end{tabular}

Note: BDL=Below the detection limit.1=Gageri PHCN, 3=Gageri Sale Hassan House, 4=Old campus Unijos, 6=Hayeni Delimi, 7=Alasari, 11=Yashanu Yareke, 12=AladeDelimi 13=Alade Delimi 2, 14=Sarki Street B, 15=Sarki Street A.

Table 2: Concentration of PCBs in water samples (ppm). 
Citation: Ibrahim EG, Gushit JS, Salami SJ, Dalen MB (2018) Accumulation of Polychlorinated Biphenyls (PCBS) in Soil and Water from Electrical Transformers Installation Sites in Selected Locations in Jos Metropolis, Plateau State, Nigeria. J Environ Anal Toxicol 8: 561. doi:10.4172/2161-0525.1000561

Page 6 of 6

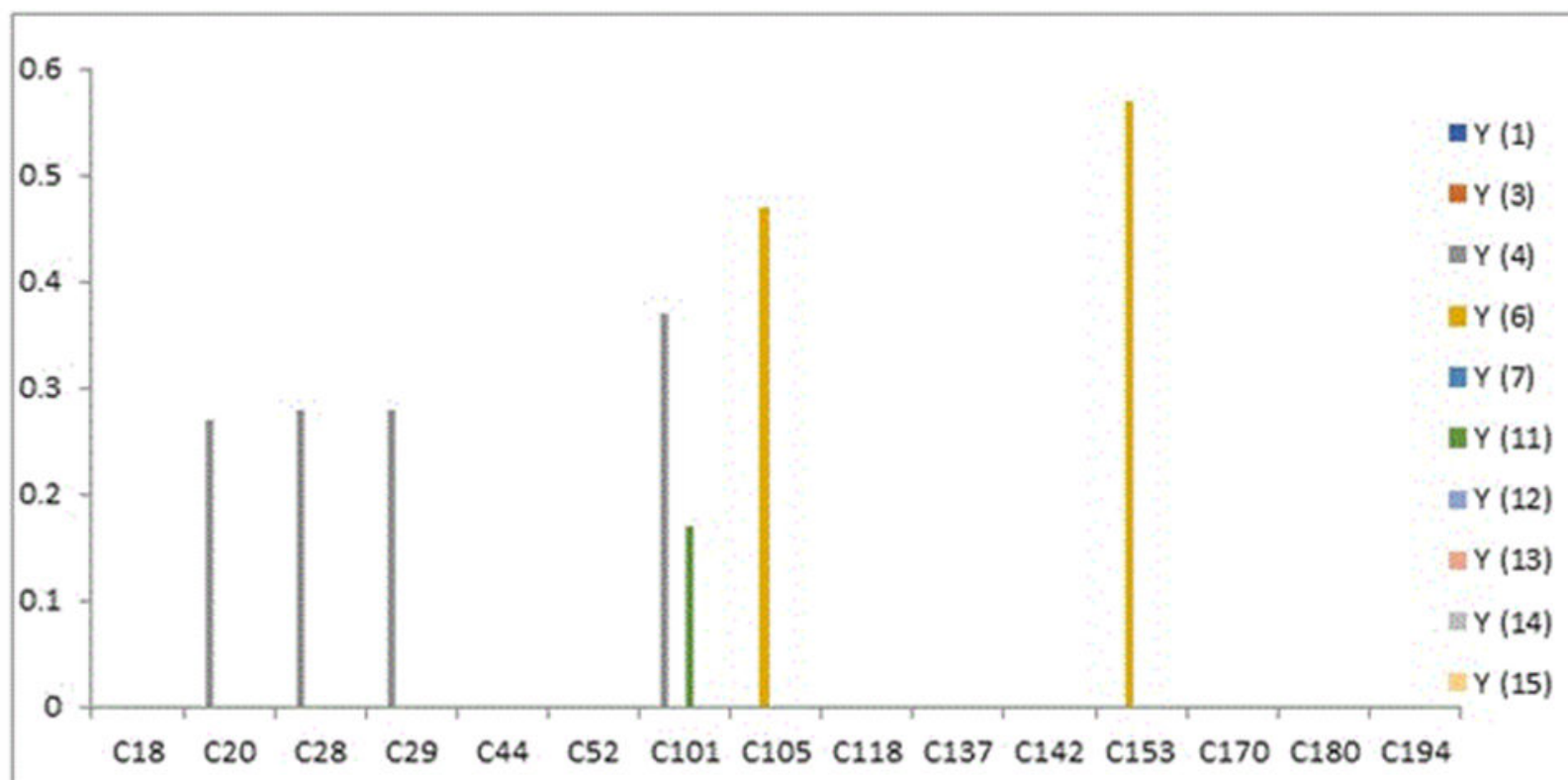

Figure 5: Comparison of Concentration of PCBs in various water samples.

From Figure 2. $\mathrm{C}_{44}, \mathrm{C}_{52}, \mathrm{C}_{118}, \mathrm{C}_{137}, \mathrm{C}_{142}, \mathrm{C}_{170}, \mathrm{C}_{180}$ and $\mathrm{C}_{194}$ were not detected in the water sample at any of the site. This study agreed with finding of Adeyi et al. [2] who found the concentration of PCBs in old transformer site in Lagos to be higher than the Alberta standard for ground water but for that of soil they also discovered the PCBs in soil is lower than the Alberta standard for industrial soil [2].

From Table 1 the concentration in the PCBs congeners ranges from $0.00-5.87 \mathrm{mg} / \mathrm{kg}$ which is similar with the result gotten by Klanora et al. [17] in Ross Island with concentration of PCBs, ranges from $0.32-0.83 \mathrm{mg} / \mathrm{kg}$, in their work they also identified and quantified congeners $\mathrm{PCB}_{28}, \mathrm{PCB}_{58}, \mathrm{PCB}_{101}, \mathrm{PCB}_{118}, \mathrm{PCB}_{153}, \mathrm{PCB}_{138}$, and $\mathrm{PCB}_{180}$, which agreed with this study except for the additional $\mathrm{PCB}_{20}, \mathrm{PCB}_{29}$, $\mathrm{PCB}_{44}, \mathrm{PCB}_{105}, \mathrm{PCB}_{137}, \mathrm{PCB}_{142}, \mathrm{PCB}_{170}$, and $\mathrm{PCB}_{194}$, that were identified and quantified in the soil sample.

\section{References}

1. EPA 3510 Method (2007) Environmental Protection Agency of the United State Methods.

2. Adeyi AA, Babalola BA, Osibanjo O (2015) Assessment of Polychlorinated Biphenyls (PCBs) in soil and water of an old transformer oil storage site in Lagos, Nigeria. A paper presented at the 10th International Symbosium on Recent Developments in POPs Analysis, A Global Concern. April 29-30, 2015 Preque, Czech Republic.

3. $\quad$ ESC (2015) Environmental Stewardship Concepts LLC, pp: 1-5.

4. WHO (1993) Environmental Health Criteria 140: Polychlorinated Biphenyls and Terphenyls. 2nd edn. WHO Geneva.

5. AENV (Alberta Environment) (2014) Alberta Tier 1 Soil and groundwater Remediation and Guidelines.

6. IARC (International Agency for Research on Cancer) (2018) Preamble to the IARC Monographs, International Agency for Research in Cancer, Lyon, France.
7. Zani C, Toninelli G, Filisetti B, Donato F (2013) Polychlorinated Biphenyls and cancer. An Epidemiological Assessment, Journal of Environmental Science and Health, Part C: Environmental Carcinogenesis and Ecotoxicology Reviews 31: 99-144.

8. Lauby-Secretan B, Loomis D, Grosse Y, El Ghissassi F, Bouvard V, et al. (2013) Carcinogenicity of Polychlorinated Biphenyls. The Lancet Oncology 14: 287-288.

9. Anyinam CA (1991) Transbounding movement of hazardous waste, the case of toxic waste dumping in Africa. International Journal of Health Service 21: 759-778.

10. Adeyemi D, Ukpo G, Anyakora C, Uyimadu J (2009) Polychlorinated Biphenyls in Fish samples from Lagos, Nigeria. African Journal of Biotechnology 8: 2811-2815.

11. Osibanjo O (1994) Review of chlorinated Hydrocarbon Substances in African Aquatic Environment. FAO Fish Rept 502: 37-45.

12. Fagbote EO, Olanipekun EO (2010) Levels of Polycyclic Aromatic Hydrocarbons and Polychlorinated Biphenyls in Sediment of Bitumen Deposit impacted area. International Journal of Environmental Science and Technology 7: 561-570.

13. Bentum JK, Dodoo DK, Kwakye PK (2012) Accumulation of metals and polychlorinated biphenyls (PCBs) in soils around electric transformers in the central region of Ghana. Adv Appl Sci Res 3: 634-643.

14. Census (2006) Federal Republic of Nigeria. National Bureau of Statistics.

15. EPA 3550 Method (2007) Environmental Protection Agency of the United State Methods.

16. AENV (Alberta Environment) (2009) Alberta Tier 1 Soil and groundwater Remediation and Guidelines.

17. Klánová J, Matykiewiczová N, Máčka Z, Prošek P, Láska K, et al. (2008) Persistent organic pollutants in soils and sediments from James Ross Island, Antarctica. Environmental Pollution 152: 416-423. 